\title{
Penerapan Model Pembelajaran Berbasis Masalah untuk Meningkatkan Hasil Belajar Kimia Siswa SMA Negeri 1 Takalar
}

\author{
Yupriana Asis \\ SMA Negeri 1 Takalar, Kabupaten Takalar - Provinsi Sulawesi Selatan \\ Corresponding Author. Email: yuprianaasis@gmail.com
}

\begin{abstract}
This study aims to improve chemistry learning outcomes in SMA Negeri 1 Takalar students through the application of a problem-based learning model. This study uses a classroom action research method. The subjects of this study were 38 students of class X IPA1. Data collection was carried out through observation, tests, and documentation. The data analysis technique of this research is using descriptive analysis. The results of this study indicate that in the first cycle the average score of student learning outcomes was 8.04 in the high category, in the second cycle the average score of learning outcomes was 8.84 with the very high category. Based on the results of this analysis, it can be concluded that the learning outcomes of students in class X IPA1 chemistry can be improved through the application of problem-based learning models.
\end{abstract}

\begin{abstract}
Abstrak: Penelitian ini bertujuan untuk meningkatkan hasil belajar kimia pada siswa SMA Negeri 1 Takalar melalui penerapan model pembelajaran berbasis masalah. Penelitian ini menggunakan metode penelitian tindakan kelas. Subjek penelitian ini adalah siswa kelas X IPA $\mathrm{I}_{1}$ yang berjumlah 38 orang. Pengumpulan data dilakukan melalui observasi, tes, dan dokumentasi. Teknik analisis data penelitian ini menggunakan analisis deskriptif. Hasil penelitian ini menunjukkan bahwa pada siklus I diperoleh skor rata-rata hasil belajar siswa adalah 8,04 dengan kategori tinggi, pada siklus II diperoleh skor rata- rata hasil belajar adalah 8,84 dengan kategori sangat tinggi. Berdasarkan hasil analisis ini dapat disimpulkan bahwa hasil belajar kimia siswa kelas $X$ IPA $_{1}$ dapat ditingkatkan melalui penerapan model Pembelajaran berbasis masalah.
\end{abstract}

Article History

Received: 19-02-2021

Revised: 06-03-2021

Published: 14-04-2021

Key Words:

Problem-Based Learning, Learning Outcomes

\section{Sejarah Artikel}

Diterima: 19-02-2021

Direvisi: 06-03-2021

Diterbitkan: 14-04-2021

\section{Kata Kunci:}

Pembelajaran Berbasis Masalah, Hasil Belajar

How to Cite: Asis, Y. (2021). Penerapan Model Pembelajaran Berbasis Masalah untuk Meningkatkan Hasil Belajar Kimia Siswa SMA Negeri 1 Takalar. Jurnal Teknologi Pendidikan : Jurnal Penelitian dan Pengembangan Pembelajaran, 6(1). doi:https://doi.org/10.33394/jtp.v6i1.3580

doi https://doi.org/10.33394/itp.v6i1.3580

This is an open-access article under the CC-BY-SA License.

\section{Pendahuluan}

Guru sebagai salah satu penentu kualitas sumber daya manusia seharusnya memperoleh prioritas utama dalam upaya pengembangan kemampuan profesionalnya. Ilmu yang mereka miliki akan diajarkan kepada siswanya dengan berbagai cara yang mereka ketahui. Oleh karena itu, seorang guru harus cakap dalam bidangnya, sebab masalah yang mereka hadapi harus dapat dipecahkan dengan cara mereka sendiri, sesuai dengan karakteristik potensi akademik, mental dan kultur siswa yang mereka hadapi.

Guru kimia di dalam kelas merupakan petugas yang berdiri paling depan dalam rangka memberi arah kepada peserta didik yang belajar kimia. Sudah barang tentu penguasaan materi pelajaran dan kemampuannya menyajikan materi dengan berbagai pendekatan merupakan kunci utama profesionalisme dan keberhasilannya sebagai guru kimia. Peranan guru kimia sangat menentukan dalam upaya meningkatkan hasil belajar kimia di sekolah, maka kualitas pembelajaran oleh guru kimia di sekolah perlu ditingkatkan secara optimal. 
Tugas mengajar bagi seorang guru memang bukanlah suatu pekerjaan yang ringan, ia harus berhadapan dengan sekelompok siswa yang latar belakangnya beraneka ragam. Mereka adalah makhluk yang memerlukan bimbingan dan pembinaan untuk menuju kedewasaan, siswa setelah mengalami proses pendidikan dan pengajaran diharapkan menjadi manusia dewasa yang sadar akan tanggung jawabnya dan bisa mandiri. Oleh karena tugas guru yang berat itu, maka dalam peranannya sebagai pengajar harus selalu menggunakan strategi atau model yang tepat dalam menyajikan suatu bahan pelajaran, sehingga apa yang diajarkan kepada siswa dapat dikuasai dengan baik.

Hasil pembelajaran kimia di sekolah menengah atas kurang menggembirakan, disamping rendahnya nilai kimia yang belum mencapai skor rata-rata 7,00, diantaranya juga menunjukkan ketidakmampuan anak-anak untuk menghubungkan antara yang dipelajari dan bagaimana pengetahuan itu dimanfaatkan untuk memecahkan persoalan sehari-hari. Jika diamati sebuah kelas, maka hampir di setiap sekolah peran guru sangat dominan. Guru menjadi penguasa kelas, ceramah yang monoton menjadi menu utama untuk mengajarkan materi, dan guru menjadi satu-satunya sumber inspirasi dan pengetahuan. Untuk itu diperlukan suatu strategi pembelajaran yang lebih memberdayakan siswa. Strategi belajar yang tidak mengharuskan siswa menghafal fakta-fakta, tetapi sebuah strategi yang mendorong siswa mengkonstruksikan pengetahuan di benak mereka sendiri.

Salah satu usaha untuk meningkatkan hasil belajar kimia siswa adalah dengan memperbaiki cara mengajarkannya. Sesuai dengan ciri kimia bahwa kimia itu didalamnya diatur oleh suatu kaidah-kaidah, maka seorang guru kimia dalam mengajar harus memegang pada suatu prinsip. Prinsip mengajar yang digunakan perlu diusahakan dapat membuat siswa lebih menguasai konsep-konsep yang sedang dipelajari, ini berarti siswa harus digiring untuk mengalami sendiri proses belajar, memaknai, mengambil keputusan dan mencapai tujuan pembelajaran dengan mengoptimalkan keterlibatan potensi kecerdasan mereka.

Saat ini dibutuhkan model pembelajaran yang dapat menghidupkan suasana kelas. Dengan konsep ini, hasil pembelajaran diharapkan akan lebih bermakna dan berkesan bagi siswa. Proses pembelajaran berlangsung secara alamiah dalam bentuk kegiatan siswa bekerja dan mengalami, bukan lagi transfer pengetahuan dari otak ke otak atau dari guru ke siswa. Siswa perlu mengerti apa makna belajar, apa manfaatnya, dan bagaimana cara mencapainya. Mereka akan menyadari bahwa apa yang mereka pelajari pada saat ini akan berguna bagi hidupnya nanti. Dalam upaya itu, guru hanya bertindak sebagai pengarah, pembimbing, mediator dan fasilitator.

Karena orientasi di dalam pendidikan adalah peserta didik, maka kegiatan mengajar akan mempengaruhi kegiatan peserta didik. Oleh karena itu, peserta didik harus dibekali bagaimana belajar dari hal-hal yang berbasis masalah. Untuk itu peserta didik harus dilatih untuk mengenali dan menyelesaikan masalah. Di dalam menyelesaikan masalah, peserta didik perlu memahami proses menyelesaikan masalah tersebut dan menjadi terampil di dalam memilih dan mengidentifikasi kondisi dan konsep yang relevan, mencari generalisasi, merumuskan rencana penyelesaian dan mengorganisasikan keterampilan yang telah dimiliki sebelumnya.

Suatu metode mengajar dapat dikatakan efektif apabila tujuan pembelajaran dapat dicapai dengan kata lain keefektifan metode mengajar ditentukan oleh keberhasilan peserta didik dalam menguasai materi yang diajarkan dengan metode tersebut. Dalam hal ini salah satu metode mengajar yang tepat dan efektif untuk merefleksikan orientasi tersebut adalah pembelajaran berbasis masalah, karena metode ini memberikan kesempatan yang luas kepada 
peserta didik untuk membangun, mengenali dan memecahkan sendiri masalah nyata yang dihadapinya (Akbar, 2019; Suarni, 2021).

Hasil wawancara terbatas dengan beberapa siswa SMA Negeri 1 Takalar diperoleh informasi bahwa sebagian dari mereka sangat kesulitan untuk menjawab soal-soal yang diberikan, karena mereka tidak mengerti maksud dari soal tersebut. Akibatnya siswa merasa bahwa kimia itu adalah pelajaran yang sangat sulit. Oleh karena itu sejak dini siswa harus dilatih dan diperhadapkan pada berbagai situasi berbasis masalah, ini merangsang mereka untuk berupaya memecahkan bermacam-macam masalah.

Kimia sebagai mata pelajaran yang penting, karenanya siswa dituntut untuk menguasai pelajaran ini di sekolah. Untuk itu, guru yang mempunyai peranan yang cukup penting, dimana hasil belajar siswa bukan hanya dipengaruhi oleh penguasaan guru terhadap materi pelajaran tetapi juga model pembelajaran yang digunakan oleh guru dalam kegiatan belajar mengajar, model pembelajaran berbasis masalah, adalah alternatif yang handal dan cocok untuk mengatasi masalah ini. Adapun penelitian ini bertujuan untuk meningkatkan hasil belajar kimia pada siswa SMA Negeri 1 Takalar melalui penerapan model pembelajaran berbasis masalah.

\section{Metode Penelitian}

Metode penelitian ini adalah penelitian tindakan yang berbasis kelas (Class Action Research), tindakan dilakukan dengan menerapkan model pembelajaran berbasis masalah pada pembelajaran kimia subjek penelitian ini adalah siswa kelas X IPA1 SMA Negeri 1 Takalar yang berjumlah 38 siswa. Berdasarkan diskusi intensif dengan guru, kepala sekolah, maka penelitian ini pelaksanaannya dalam dua siklus dengan 12 kali pertemuan.

Data dikumpulkan selama 2 siklus penuh, untuk data tentang kemampuan siswa dalam memahami konsep-konsep kimia yang diajarkan dengan menggunakan model pembelajaran berbasis masalah diambil selama proses belajar mengajar berlangsung dan secara formal diambil dari hasil tes setiap akhir siklus dan tes lainnya, selama dua siklus penuh. Lebih detail data mengenai kualitas pembelajaran kimia dengan menggunakan model pembelajaran berbasis masalah dalam proses belajar mengajar kimia diambil melalui lembar observasi pada setiap pertemuan, diakhir siklus diedarkan kuesioner tanggapan siswa.

Data yang dikumpulkan dianalisis secara kualitatif dan kuantitatif. Data mengenai kemampuan pemahaman (prestasi belajar) siswa terhadap materi yang telah diberikan dengan menggunakan model pembelajaran berbasis masalah, dianalisis secara kuantitatif untuk melihat pengaruh perbaikan akibat intensitas dan kualitas penggunaan model pembelajaran berbasis masalah. Indikator keberhasilan penelitian ini bagi siswa adalah apabila hasil tes sudah menunjukkan adanya peningkatan ketuntasan kelas. Adapun untuk keperluan analisis kualitatif digunakan teknik kategorisasi standar yang ditetapkan oleh Departemen Pendidikan dan Kebudayaan (Endah Lestari, 2004). Yang menjadi indikator keberhasilan/kinerja penelitian tindakan ini adalah bila hasil belajar kimia siswa mencapai ketuntasan kelas yakni penguasaan kimia siswa kelas X IPA1 SMA Negeri 1 Takalar mencapai 75\%, indikator lainnya adalah peningkatan antusiasme guru-siswa dalam proses pembelajaran kimia dengan menerapkan model pembelajaran berbasis masalah, kecenderungan suasana pembelajaran yang menarik/kondusif, dan indikator kualitatif-positif lainnya. 


\section{Hasil Penelitian}

\section{Analisis Deskriptif Siklus I}

Setelah selesai penyajian materi satu pokok bahasan pada Siklus I dilaksanakan tes hasil belajar dalam bentuk ulangan harian. Adapun hasil analisis deskriptif terhadap skor perolehan siswa setelah diterapkannya pembelajaran dengan menggunakan penggunaan model pembelajaran berbasis masalah selama Siklus I dapat dilihat pada Tabel 1 sebagai berikut:

Tabel 1. Statistik Skor Hasil Belajar Siswa pada Siklus I

\begin{tabular}{|c|c|}
\hline Statistik & Nilai Statistik \\
\hline Subjek & 38 \\
Skor ideal & 10 \\
Skor tertinggi & 10 \\
Skor terendah & 5,2 \\
Rentang skor & 4,8 \\
Skor rata-rata & 8,04 \\
Standar deviasi (simpangan baku) & 1,13 \\
\hline
\end{tabular}

Dari tabel di atas terlihat bahwa skor rata-rata hasil belajar siswa terhadap materi pada Siklus I dengan Pokok Bahasan Hidrokarbon adalah 8,04 dari skor ideal yang mungkin dicapai yaitu 10 dan skor terendah yang mungkin dicapai yaitu 0. Jika skor hasil belajar siswa di atas dikelompokkan ke dalam lima kategori maka diperoleh distribusi frekuensi skor seperti ditunjukkan pada Tabel 2 berikut:

Tabel 2. Distribusi Frekuensi Skor Hasil Belajar Siswa pada Tes Siklus I

\begin{tabular}{|c|c|c|c|}
\hline Skor & Kategori & Frekuensi & Persentase \\
\hline $0-3,4$ & Sangat rendah & 0 & 0 \\
$3,5-5,4$ & Rendah & 1 & 2,63 \\
$5,5-6,4$ & Sedang & 4 & 10,53 \\
$6,5-8,4$ & Tinggi & 23 & 60,53 \\
$8,5-10$ & Sangat tinggi & 10 & 26,32 \\
\hline \multicolumn{2}{|c|}{ Jumlah } & 38 & 100,0 \\
\hline
\end{tabular}

Setelah digunakan kategorisasi pada Tabel 2 di atas, terlihat bahwa dari 38 orang siswa yang dijadikan subjek penelitian, tidak terdapat siswa yang berada pada kategori sangat rendah, hanya 1 orang $(2,63 \%)$ berada pada kategori rendah, 4 orang $(10,53 \%)$ berada pada kategori sedang, 23 orang $(60,53 \%)$ berada pada kategori tinggi, dan 10 siswa $(26,32 \%)$ yang berada pada kategori sangat tinggi.

Apabila skor rata-rata hasil belajar tes Siklus I yaitu 8,04 dikategorisasikan ke dalam kategorisasi standar (skala lima) maka skor tersebut berada pada kategori tinggi. Jadi, dapat disimpulkan bahwa terjadi peningkatan hasil belajar siswa setelah diberi tindakan pada Siklus I. Hal ini ditandai dengan meningkatnya skor rata-rata hasil belajar siswa sebesar 4,88 pada tes awal menjadi 8,04 pada Siklus I, atau terjadi peningkatan dari kategori rendah menjadi kategori tinggi.

\section{Analisis Deskriptif Hasil Belajar Tes Akhir Siklus II}

Dari analisis terhadap skor hasil belajar siswa setelah diterapkan pembelajaran dengan penggunaan model pembelajaran berbasis masalah selama berlangsungnya Siklus II dapat dilihat pada Tabel 3 berikut: 
Tabel 3. Statistik Skor Hasil Belajar Siswa pada Siklus II

\begin{tabular}{|c|c|}
\hline Statistik & Nilai Statistik \\
\hline Subjek & 38 \\
Skor ideal & 10 \\
Skor tertinggi & 10 \\
Skor terendah & 6 \\
Rentang skor & 4 \\
Skor rata-rata & 8,84 \\
Standar deviasi (simpangan baku) & 0,83 \\
\hline
\end{tabular}

Dari data di atas, jika skor hasil belajar kimia dikelompokkan ke dalam lima kategori, maka diperoleh distribusi frekuensi skor yang disajikan pada Tabel 4 berikut ini:

Tabel 4. Distribusi Frekuensi Skor Hasil Belajar Siswa pada Tes Siklus II

\begin{tabular}{|c|c|c|c|}
\hline Skor & Kategori & Frekuensi & Persentase \\
\hline $0-3,4$ & Sangat rendah & 0 & 0 \\
$3,5-5,4$ & Rendah & 0 & 0 \\
$5,5-6,4$ & Sedang & 1 & 2,63 \\
$6,5-8,4$ & Tinggi & 10 & 26,32 \\
$8,5-10$ & Sangat tinggi & 27 & 71,05 \\
\hline \multicolumn{2}{|c|}{ Jumlah } & 38 & 100,0 \\
\hline
\end{tabular}

Setelah digunakan kategorisasi pada Tabel diatas, terlihat bahwa dari 38 orang siswa yang dijadikan subjek penelitian, tidak terdapat siswa yang berada pada kategori sangat rendah dan kategori rendah, 1 orang $(2,63 \%)$ yang berada pada kategori sedang, 10 orang $(26,32 \%)$ yang berada pada kategori tinggi, dan 27 orang $(71,05 \%)$ yang berada pada kategori sangat tinggi.

Dari skor rata-rata hasil belajar siswa untuk Siklus II yaitu sebesar 8,84 setelah dikategorisasikan, diketahui bahwa hasil belajar kimia setelah diadakan pembelajaran dengan penggunaan model pembelajaran berbasis masalah berada pada kategori sangat tinggi. Selanjutnya Tabel 5 akan memperlihatkan peningkatan hasil belajar siswa setelah dilaksanakan pembelajaran dengan penggunaan model pembelajaran berbasis masalah dalam proses belajar mengajar pada Siklus I dan sebelum pembelajaran (hasil tes awal).

Tabel 5. Distribusi Frekuensi Skor Hasil Tes Awal dan setelah Proses

Pembelajaran pada Siklus I

\begin{tabular}{|c|c|c|c|c|c|}
\hline & & \multicolumn{2}{|c|}{ Frekuensi } & \multicolumn{2}{c|}{ Persentase } \\
\cline { 3 - 6 } Skor & Kategori & Tes Awal & Siklus I & Tes Awal & Siklus I \\
\hline $0-3,4$ & Sangat rendah & 4 & 0 & 10,53 & 0 \\
$3,5-5,4$ & Rendah & 25 & 1 & 65,79 & 2,63 \\
$5,5-6,4$ & Sedang & 4 & 4 & 10,53 & 10,53 \\
$6,5-8,4$ & Tinggi & 5 & 23 & 13,16 & 60,53 \\
$8,5-10$ & Sangat tinggi & 0 & 10 & 0 & 26,32 \\
\hline
\end{tabular}

Dari hasil analisis deskriptif di atas menunjukkan bahwa setelah pemberian tindakan selama siklus pertama, skor rata-rata hasil belajar siswa mengalami peningkatan. Pada Tes Awal, skor rata-rata hasil belajar siswa yaitu 4,88 yang apabila dikategorikan ke dalam kategorisasi standar (skala lima) maka ia berada pada kategori rendah. Pada Siklus I meningkat menjadi 8,04 yang apabila dikategorikan ke dalam skala lima maka berada pada kategori tinggi. Ini berarti, bahwa pembelajaran kimia dengan penggunaan model pembelajaran berbasis masalah pada siklus pertama dapat meningkatkan hasil belajar kimia siswa Kelas X IPA 1 SMA Negeri 1 Takalar, yakni dari kategori rendah menjadi kategori tinggi. 
Tabel 6. Distribusi Frekuensi Skor setelah Pembelajaran dari Siklus I ke Siklus II

\begin{tabular}{|c|c|c|c|c|c|}
\hline & & \multicolumn{2}{|c|}{ Frekuensi } & \multicolumn{2}{c|}{ Persentase } \\
\cline { 3 - 6 } Skor & Kategori & Siklus I & Siklus II & Siklus I & Siklus II \\
\hline $0-3,4$ & Sangat rendah & 0 & 0 & 0 & 0 \\
$3,5-5,4$ & Rendah & 1 & 0 & 2,63 & 0 \\
$5,5-6,4$ & Sedang & 4 & 1 & 10,53 & 2,63 \\
$6,5-8,4$ & Tinggi & 23 & 10 & 60,53 & 26,32 \\
$8,5-10$ & Sangat tinggi & 10 & 27 & 26,32 & 71,05 \\
\hline
\end{tabular}

Dari hasil analisis deskriptif di atas menunjukkan bahwa setelah pemberian tindakan selama dua siklus, skor rata-rata hasil belajar siswa mengalami peningkatan. Pada Siklus I, skor rata-rata hasil belajar siswa yaitu 8,04 yang apabila dikategorikan ke dalam kategorisasi standar (skala lima) maka ia berada pada kategori tinggi. Pada Siklus II meningkat menjadi 8,84 yang apabila dikategorikan ke dalam skala lima maka berada pada kategori sangat tinggi. Ini berarti, bahwa pembelajaran kimia dengan penggunaan model pembelajaran berbasis masalah dapat meningkatkan hasil belajar kimia siswa kelas X IPA 1 SMA Negeri 1 Takalar.

\section{Refleksi Umum}

Setelah pembelajaran pada siklus pertama dan memasuki siklus kedua, siswa semakin bersemangat dalam mengikuti pembelajaran kimia dengan model pembelajaran berbasis masalah. Selain itu banyak diantara mereka yang sudah berani mengemukakan pendapat dan memunculkan masalah sekaligus memecahkan masalah, walaupun kadang kala pendapat tersebut kurang relevan dengan materi pembelajaran kimia yang sesungguhnya. Ada beberapa siswa mengacungkan tangan berulang-ulang sebagai pertanda semangat siswa untuk mengikuti pembelajaran, bahkan sebagian besar sudah dapat memberikan komentar secara bersama-sama (bahkan secara sendiri-sendiri), terhadap suatu masalah yang diberikan oleh guru.

\section{Rekomendasi Tindak Lanjut pada Pembelajaran Kimia Berikutnya}

Berdasarkan pada hasil penelitian ini, yakni pada siklus I dan siklus II, maka rekomendasi yang dapat dilakukan oleh para guru Kimia, antara lain :

1) Pada pembelajaran kimia berbasis masalah, guru sudah harus siap memunculkan masalah pada setiap pertemuan, atau paling tidak pada setiap pokok bahasan apabila memungkinkan, bila tidak maka guru harus memilih pokok bahasan yang mana yang sesuai dengan model/strategi pembelajaran yang akan digunakan. Akan lebih baik jika guru telah punya daftar masalah sesuai dengan pokok bahasan masing-masing, sehingga pada saat akan digunakan semuanya sudah siap, dan sewaktu-waktu dapat dikembangkan sesuai perkembangan paradigma pembelajaran terbaru.

2) Hendaknya guru untuk terus melakukan penelitian tindakan, walaupun sifatnya kecilkecilan, membiasakan diri menggunakan instrumen pembelajaran misalnya LKS, Lembar Observasi dan Skenario Pembelajaran. Dengan demikian guru akan selalu tampil prima dalam proses pembelajaran dan diharapkan siswa akan mendapatkan hasil belajar yang lebih baik dan lebih stabil.

3) Selalu berusaha mendiskusikan berbagai masalah pembelajaran dengan teman-teman guru, mengenai langkah-langkah perbaikan (yang lebih baik) yang direkomendasikan oleh kebijakan dari atas dan diinginkan oleh siswa. 
4) Setiap semester sebelum pembelajaran dimulai, tim guru menelaah kurikulum dan mengumpulkan/mengadakan literatur utama yang terkait langsung dengan bahan ajar yang akan dikembangkan.

5) Setiap semester sebelum pembelajaran dimulai, tim guru merencanakan strategi dan model/metode pembelajaran yang akan dipergunakan, serta membuat dan mengembangkan skenario pembelajaran kimia, sesuai dengan model/metode dan materi ajar yang akan dipergunakan.

6) Setiap selesai topik pembelajaran kimia, guru sebaiknya meminta tanggapan/pendapat siswa secara tertulis terhadap metode pembelajaran yang telah dipergunakan, sebagai penilaian kualitatif bagi kinerja guru.

7) Menganalisis refleksi yang diberikan oleh siswa dan mendiskusikannya dengan tim guru kimia di sekolah.

8) Mendiskusikan rencana-rencana lain yang berhubungan dengan pelaksanaan pembelajaran kimia, misalnya pemberian hadiah kecil-kecilan kepada siswa yang berprestasi atau siswa yang meningkat prestasinya.

9) Pada setiap pembelajaran kimia, memberikan pujian/dukungan kepada siswa yang memberikan jawaban yang tepat/benar.

10) Pembelajaran kimia berbasis masalah tidak harus di dalam kelas, pembelajaran kimia dengan strategi/model yang lainpun demikian, artinya siswa dapat belajar kimia di luar kelas sambil menikmati suasana lain yang bernuansa rekreatif. Gurupun dapat merancang bentuk-bentuk permainan kimia untuk mendongkrak semangat dan imajinasi siswa, pendek kata guru dituntut untuk berimprovisasi agar pembelajaran lebih hidup dan lebih menarik.

\section{Kesimpulan}

Berdasarkan pembahasan hasil penelitian maka dapat ditarik kesimpulan bahwa hasil belajar kimia dan kualitas proses pembelajaran kimia pada siswa Kelas X IPA ${ }_{1}$ SMA Negeri 1 Takalar mengalami peningkatan setelah diadakan pembelajaran dengan menggunakan model pembelajaran berbasis masalah, dengan indikasi sebagai berikut : (1) Skor rata-rata hasil belajar kimia siswa Kelas X IPA 1 SMA Negeri 1 Takalar setelah diberi tindakan pada Siklus I adalah 8,04 dari skor ideal 10 atau berada dalam kategori tinggi. (2) Skor rata-rata

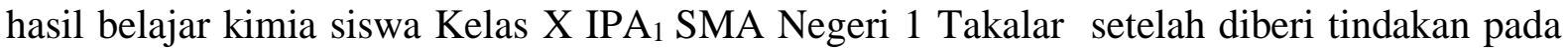
Siklus II adalah 8,84 dari skor ideal 10 atau berada pada kategori sangat tinggi, ini berarti indikator keberhasilan/kinerja penelitian tindakan ini telah dicapai, karena hasil belajar kimia siswa mencapai ketuntasan kelas 88,4\%, melampaui standar indikator kinerja yang ditargetkan, yakni penguasan kimia mencapai 70\%. (3) Pembelajaran kimia dengan menggunakan pembelajaran berbasis masalah dapat meningkatkan hasil belajar kimia siswa Kelas X IPA 1 SMA Negeri 1 Takalar, yang indikatornya berupa peningkatan skor rata-rata hasil belajar siswa pada Siklus I sebesar 3,16. Peningkatan skor rata-rata hasil belajar siswa pada dari Siklus I ke Siklus II sebesar 0,8. Meningkatnya prosentase kehadiran siswa, pada Siklus I sebanyak 98,25\% sebanyak 12 kali pertemuan menjadi 99,12\% dengan 12 kali pertemuan pada Siklus II. Hal ini berarti bahwa motivasi siswa untuk mengikuti pembelajaran dengan penggunaan model pembelajaran berbasis masalah semakin meningkat

\section{Saran}

Dari hasil penelitian yang diperoleh, baik peningkatan hasil belajar kimia siswa maupun peningkatan kualitas pembelajaran, yang ditandai dengan adanya perubahan-perubahan 
kualitatif-positif yang dialami siswa, dengan demikian dapat diajukan saran-saran sebagai berikut:

1) Direkomendasikan agar guru selalu merencanakan strategi dan model/metode pembelajaran yang akan dipergunakan, serta membuat dan mengembangkan skenario pembelajaran kimia, sesuai dengan metode dan materi ajar yang akan dipergunakan.

2) Setiap selesai topik pembelajaran kimia, guru sebaiknya meminta tanggapan/pendapat siswa secara tertulis terhadap model/metode pembelajaran yang telah dipergunakan, sebagai penilaian kualitatif bagi kinerja guru, kemudian menganalisis hasil refleksi yang diberikan oleh siswa dan mendiskusikannya dengan teman sejawat di sekolah.

3) Dalam pembelajaran kimia, guru diharapkan senantiasa memperhatikan dan melibatkan konteks (lingkungan) siswa, sehingga konsep-konsep yang diterima siswa menjadi lebih bermakna.

4) Pembelajaran kimia berbasis masalah tidak harus di dalam kelas, pembelajaran kimia dengan strategi/model yang lainpun demikian, artinya siswa dapat belajar kimia di luar kelas sambil menikmati suasana lain yang lebih segar bernuansa rekreatif. Gurupun dapat merancang bentuk-bentuk permainan kimia untuk mendongkrak semangat dan imajinasi siswa, pendek kata guru dituntut untuk berimprovisasi agar pembelajaran kimia di sekolah lebih hidup, lebih menarik/rekreatif dan tentu saja lebih menyenangkan

\section{Daftar Pustaka}

Akbar, A. (2019). Implementasi Model Pembelajaran Berbasis Masalah untuk Meningkatkan Hasil Belajar Siswa pada Mata Pelajaran PKn di SMA Negeri 1 Batukliang Utara. Jurnal Kependidikan: Jurnal Hasil Penelitian dan Kajian Kepustakaan di Bidang Pendidikan, Pengajaran dan Pembelajaran, 5(1), 1-7. doi:https://doi.org/10.33394/jk.v5i1.1386

Boediono. (2002). Kompetensi Dasar Kimia Pelajaran Kimia SMP dan Madrasah Tsanawiyah. Jakarta: Pusat Kurikulum Balitbang Depdiknas.

Glazer, E. (2001). Problem Based Instruction. ttp://www.coe.uga.edu.epltt/problem basedinstruct.htm

Hudoyo, Herman. (1990). Strategi Mengajar Belajar Kimia. Malang: IKIP Malang (2001). Pengembangan Kurikulum dan Pembelajaran Matemaitka. JICA. Jurusan Pendidikan Kimia Universitas Negeri Malang.

Ibrahim, Muhammad. (2003). Pengajaran Berdasarkan Masalah. Jakarta: Departemen Pendidikan Nasional.

Ibrahim, Muhammad., Nur. (2000). Pembelajaran Berdasarkan Masalah. Surabaya: Universitas Negeri Surabaya.

Muhkal, Mappaita. (1999). Menumbuhkan Kemampuan Mengajar kimia. Eksponen. Jurnal Pendidikan Kimia dan Kimia Vol. 2. No. 1. Hal. 1-121. FMIPA Uneversitas Negeri Makassar.

Suarni, G., Rizka, M., \& Zinnurain, Z. (2021). Analisis Pengaruh Penerapan Model Pembelajaran Sains Teknologi Masyarakat Terhadap Hasil Belajar Siswa. Jurnal Paedagogy, 8(1), 31-38. doi:https://doi.org/10.33394/jp.v8i1.3226

Suherman, E. Turmudi,. Dkk. (2003). Strategi Pembelajaran Kimia Kontemporer. Malang: JICA

Sukoriyanto. (2001). Langkah-langkah dalam Pengajaran Kimia dengan Menggunakan Metode Pemecahan Masalah. Jurnal Kimia atau Pembelajarannya. Tahun VII, Nomor 2 hal. 103-111. JICA. Bandung. 
Upu, Hamzah. (2003). Problem Possing dan Problem Solving dalam Pembelajaran Kimia. Pustaka Ramadan

Wahyuni, Andi. (2005). Peningkatan Hasil Belajar Matematika Siswa Kelas $I_{1} S M P$ Negeri 14 Makassar Melalui Pembelajaran Berbasis Masalah. Skripsi, Jurusan Matematika FMIPA UNM Makassar. 